\title{
Grammatikalisering af danske præpositioner
}

\author{
Kasper Boye, Maria Messerschmidt, \\ Josefine Straube Hansen \\ \& Victoria Schaffalitzky de Muckadell
}

\begin{abstract}
Messerschmidt \& al. (2018) made a distinction between grammatical and lexical prepositions based on the functional theory of grammatical status in Boye \& Harder (2012), and demonstrated that this distinction is significant for the description of agrammatic speech. The functional theory predicts that grammatical items attract less attention than lexical ones. In this paper, we use a letter detection experiment to demonstrate that this also holds for Danish prepositions. Not all grammatical-lexical preposition pairs contrasted show a significant difference between letter detection rates, however. We argue that varying degrees of differences reflect different positions in a grammaticalization cline in which a grammatical descendent is gradually distilled out of a lexical source.
\end{abstract}

\section{Nøgleord}

præpositioner, grammatisk, leksikalsk, bogstavsøgning, opmærksomhed

\section{Indledning}

Er præpositioner grammatiske eller leksikalske ord? Det spørgsmål har en lang række forskere besvaret, men ikke på samme vis. Som omtalt i Messerschmidt \& al. (2018), finder man alle tænkelige svar i litteraturen: Nogle betragter ordklassen som grammatisk en bloc (fx Harley 2006: 77, 118; jf. Chomsky 1981: 48). Andre ser den som leksikalsk en bloc (fx Jackendoff 1973; Leikin 2002), mens atter andre opfatter præpositioner som grammatisk-leksikalske hybrider (fx Mardale 201 1; Bordet \& Jamet 2010) 
eller som en ordklasse med både leksikalske og grammatiske medlemmer (fx Friederici 1982; Littlefield 2005; Kean 1979).

Ifølge den funktionelle teori om grammatisk status i Boye \& Harder (2012) er det et empirisk spørgsmål, om en given præposition er grammatisk, leksikalsk eller har både grammatiske og leksikalske betydningsvarianter. I Messerschmidt \& al. (2018) udviklede vi med afsæt i samme teori et modifaktionskriterium, som vi brugte til at klassificere betydningsvarianter af de mest frekvente præpositioner i dansk som enten grammatiske eller leksikalske. Efterfølgende viste vi i en sammenlignende undersøgelse af en person med agrammatisk afasi og en ikke-hjerneskadet kontrolperson, at klassifikationen er signifikant for beskrivelsen af agrammatisme: Agrammatisme går i højere grad ud over produktionen af præpositioner, der ifølge vores klassifikation er grammatiske, end over produktionen af præpositioner, der er leksikalske.

Den funktionelle teori definerer grammatiske tegn som diskursivt sekundære pr. konvention og leksikalske som tegn, der pr. konvention har potentialet til at være primære (Boye \& Harder 2012: 7). Denne definition indebærer en hypotese om, at grammatiske tegn alt andet lige tiltrækker sig mindre opmærksomhed end leksikalske. Hypotesen er blevet bekræftet i bogstavsøgnings- (Vinther, Boye \& Kristensen 2014) og ændringsblindhedsforsøg (Christensen \& al., under revision). I nærværende artikel ser vi på, om den holder for præpositioner. Vi undersøger med andre ord den hypotese, at præpositioner, der ifølge vores klassifikation er grammatiske, tiltrækker sig mindre opmærksomhed end præpositioner, der er leksikalske.

Undersøgelsen tager form af en bogstavsøgningstest, idet det antages, at evnen til at finde bogstaver under læsning for forståelse bl.a. er betinget af, hvor opmærksom læseren er på de ord, der har de pågældende bogstaver. Vores hypotese kan således udmøntes i følgende forudsigelse: I en bogstavsøgningstest overses der flere targetbogstaver i grammatiske præpositionsvarianter end i leksikalske.

For at afprøve, om denne forudsigelse holder stik, kontrasterer vi i bogstavsøgningstesten tre grammatiske præpositionsvarianter med tre leksikalske varianter: for (grammatisk) med for (leksikalsk) og grammatiske varianter af efter og fra med leksikalske varianter. Fælles for alle disse præpositionsvarianter er, at de i skriften har et $r$.

Artiklen er struktureret som følger: I afsnit 2 gennemgår vi kort den funktionelle teori i Boye \& Harder (2012) og det modifikationskriterium, der blev udledt af teorien i Messerschmidt et al. (2018), hvorefter vi bruger kriteriet til at klassificere de udvalgte præpositionsvarianter som gram- 
matiske eller leksikalske. Til slut i afsnit 2 giver vi en kort introduktion til undersøgelser af sproglig opmærksomhed med fokus på bogstavsøgning. I afsnit 3 præsenterer vi vores test, og i afsnit 4 resultaterne af testen. I afsnit 5 diskuterer vi resultaterne, idet vi lægger særlig vægt på det indblik, de efter vores mening giver i grammatikalisering som konventionaliseringsproces. Afsnit 6 er en kort konklusion.

\section{Teoretisk baggrund}

\subsection{En funktionel teori om grammatisk status}

Den centrale idé i Boye \& Harders (2012) teori om grammatisk status er, at grammatik-leksikon-kontrasten er et konventionelt middel til at indikere diskursprominens, dvs. til at indikere graden af "kommunikativ vigtighed" og dermed graden af opmærksomhed, der kræves. Grammatiske tegn (morfemer, ord, konstruktioner) defineres som sagt som tegn, der pr. konvention er diskursivt sekundære ("baggrundede"), mens leksikalske tegn defineres som tegn, der pr. konvention har potentialet til at være primære ("forgrundede"). Teorien er således funktionel, idet den forankrer en strukturel sondring (grammatik vs. leksikon) i en funktionel (diskursiv sekundaritet vs. potentiel primaritet), og essensen i den er semantisk: Grammatiske tegn er sekundære pr. konvention, fordi deres indhold pr. konvention er sekundært; leksikalske tegn er potentielt primære $\mathrm{i}$ kraft af, at deres indhold er potentielt primært (Boye \& Harder 2012: 13). Teorien er endvidere sprogbrugsbaseret, idet den ser grammatisk og leksikalsk status som konventioner: Konventioner opstår i og holdes i live af sprogbrugen, og de kan tilsidesættes, som når man korrigerende kontrasterer et grammatisk tegn med et andet i feg sagde: jeg købte EN cykel, ikke cyklEN. Grammatikalisering - dannelsen af grammatiske tegn - er således en konventionaliseringsproces. Dermed er teorien også kognitiv, for der er en klar sammenhæng mellem konvention og entrenchment: Tegn, der er diskursivt sekundære pr. konvention, er entrenched med diskursivt sekundær status.

\subsection{Modifikationskriteriet}

Teorien indebærer tre diagnostiske kriterier, der kan bruges til at skelne grammatiske og leksikalske tegn - eller grammatiske og leksikalske betydninger. Her skal vi kun beskæftige os med modifikationskriteriet, for som beskrevet i Messerschmidt et al. (2018), er det det eneste af de tre, der ikke er begrænset til sætningsled, og som derfor kan anvendes på præpositioner. 
Hvad angår de to øvrige kriterier, fokuskriteriet og adresseringskriteriet, henvises der til Boye \& Harder (2012: 13-18) og Messerschmidt \& al. (2018).

Modifikationskriteriet lyder således: Grammatiske tegn og betydninger kan ikke modficeres selvstændigt; leksikalske tegn og betydninger kan. Kriteriet følger af forskellen på grammatisk og leksikalsk status, som den defineres i Boye \& Harder (2012: 7, 13) (se Messerschmidt et al. 2018: 92-93): Modifikation indebærer elaborering af det, der modificeres, og elaborering tiltrækker sig opmærksomhed. Eftersom grammatiske tegn og betydninger er diskursivt sekundære pr. konvention, er de således dårlige kandidater til elaborering ved modifikation. Leksikalske tegn, der pr. konvention er potentielt primære, er derimod fuldt forenelige med modifikation. I Messerschmidt et al. (2018: 93) blev kriteriet illustreret med eksemplet i (1):

Han har løbet hurtigt.

Har er et grammatisk verbum, et hjælpeverbum, og det kan ikke modificeres af mådesadverbier som hurtigt. Det kan kun det leksikalske verbum løbet. Tilsvarende kan hjælpeverbet eller dets perfektumbetydning ikke modificeres selvstændigt af præsenssuffikset $-r$ - på trods af, at $-r$ netop er bundet til hjælpeverbet. Det er hele sagforholdet, inklusive perfektumbetydningen, der modficeres temporalt af $-r$.

\subsection{Danske prapositioner og grammatik-leksikon- sondringen}

I Messerschmidt et al. (2018) argumenteres der for, at leksikalske præpositionsvarianter kan modificeres af visse adverbier. Seks præpositionsmodificerende adverbier identificeres: kort, midt, lige (i betydningen 'præcis' eller 'hele vejen'), precis og umiddelbart. Et syvende er helt. Efter at have anvendt kriteriet på de mest frekvente danske præpositioner foreslår Messerschmidt et al. (2018) en klassifikation af betydingsvarianter af de hyppigst forekommende danske præpositioner. De observerer, at gruppen af varianter, der ifølge kriteriet er grammatiske, består af varianter, der har kasus- eller aktionsartsrelateret (fx atelicitetsmarkerende) funktion, mens den leksikalske gruppe omfatter lokativiske og temporale varianter.

I denne artikel kontrasterer vi som sagt tre grammatiske præpositionsvarianter: for og grammatiske varianter af efter og fra, med tre leksikalske varianter: for og leksikalske varianter af efter og fra. De pågældende kontraster er eksempliceret i (2) - (4), hvor a-eksemplerne har en grammatisk variant, mens b-eksemplerne har en leksikalsk. 
(2a) Emmanuel betalte for Jonas.

(2b) Emmanuel betalte før Jonas.

(3a) Han slog efter en bodybuilder til et spil ølbowling.

(3b) Han slog en bodybuilder efter et spil ølbowling.

(4a) Vi fik de lækreste snegle og croissanter fra bageren.

(4b) Vi fik de lækreste snegle og croissanter fra morgenstunden.

I overensstemmelse med den omtalte observation i Messerschmidt et al. (2018) har de grammatiske varianter kasus- eller aktionsartsrelateret funktion: For i (2a) markerer den tematiske rolle benefaktiv, efter i (3a) aktionsartsværdien atelicitet, og fra i (4a) den tematiske rolle kilde. De leksikalske varianter er - ligeledes i overensstemmelse med observationen - temporale. (5) - (7) viser, at varianterne i (2a), (3a) og (4a) netop er grammatiske, mens dem i (2b), (3b) og (4b) er leksikalske. Kun de sidstnævnte lader sig modificere af præpositionsmodificerende adverbier uden betydningsændring. Med* markerer vi således, at præpositionsvarianterne ikke lader sig modificere uden betydningsændring. (5a) er helt uacceptabel. (6a) er kun acceptabel, hvis kort læses som mådesadverbium i stedet for som præpositionsmodificerende adverbium. (7a) er kun acceptabel, hvis fra bageren læses lokativisk i stedet for som kilde.

(5a) *Kort for Jonas betalte Emmanuel.

(5b) Kort før Jonas betalte Emmanuel.

(6a) *Han slog kort efter en bodybuilder til et spil ølbowling.

(6b) Han slog en bodybuilder kort efter et spil ølbowling.

(7a) *Helt fra bageren fik vi de lækreste snegle og croissanter.

(7b) Helt fra morgenstunden fik vi de lækreste snegle og croissanter.

Af (8) - (10) og (11) - (13) fremgår det, at det i (5b), (6b) og (7b) netop er de leksikalske præpositioner, der modificeres, og ikke præpositionssyntagmerne som helhed. Man kan substituere præpositionssyntagmerne med proformer:

(8) Da betalte Emmanuel.

(9) Han slog en bodybuilder der/da.

(10) Der/da fik vi de lækreste snegle og croissanter.

Men præpositionssyntagmerne kan ikke substitueres uafhængigt af de præpositionsmodificerende adverbier. 
(11) *Kort da betalte Emmanuel.

(12) *Han slog en bodybuilder kort der/da.

(13) *Helt der/da fik vi de lækreste snegle og croissanter.

De præpositionsmodificerende adverbier er altså en del af præpositionssyntagmerne og ikke modifikatorer af dem. For yderligere diskussion af modifikationskriteriet henvises der til Messerschmidt et al. (2018: 93-97).

\subsection{Bogstavsøgning og andre undersøgelser af diskurs- prominens og opmarksomhed}

Bogstavsøgning består i, at man læser en tekst, imens man identificerer og markerer forekomster af et eller flere på forhånd givne bogstaver (targetbogstaver). Bogstavsøgning kan bruges til at undersøge, hvor opmærksom man er på forskellige ord (targetord) - og dermed ordenes diskursprominens - idet det antages, at evnen til at finde bogstaver under læsning bl.a. er betinget af, hvor opmærksom læseren er på de ord, der har de pågældende bogstaver. Jo større en andel af targetbogstaverne man finder, desto mere opmærksom antages man at være på de ord, bogstaverne forekommer i.

Bogstavsøgning har tidligere været anvendt til at påvise forskelle i opmærksomhed på grammatiske og leksikalske ord. På grundlag af kriterier i Boye \& Harder (2012) kontrasterede Vinther, Boye \& Kristensen (2014) danske grammatiske ord (artikler og hjælpeverber) med leksikalske ord (pronomener, proprier og fuldverber) på samme eller omtrent samme plads i i øvrigt identiske tekster. De bad forsøgsdeltagere læse teksterne med henblik på at kunne besvare efterfølgende forståelsesspørgsmål og samtidig overstrege forekomster af bogstaverne $n$ og $t$, som forekom i targetordene. Resultatet af undersøgelsen var, at forsøgsdeltagerne overså signifikant flere forekomster af $n$ og $t$ i de grammatiske end i de leksikalske ord. Ligeledes på grundlag af kriterier i Boye \& Harder (2012) klassificerede Kalledsøe, Vinther \& Boye (2016) alle ord i danske alderssvarende tekster som enten grammatiske og leksikalske. De bad forsøgspersoner fra 0., 2., 4. og 6. klasse samt voksne læse teksterne med henblik på besvarelse af forståelsesspørgsmål og samtidig overstrege forekomster af bogstavet $t$. Resultatet af undersøgelsen var, at mens personer fra 0. klasse, der forventedes ikke at kunne læse endnu, ikke gjorde forskel på grammatiske og leksikalske ord, overså ældre forsøgsdeltagere signifikant flere forekomster af $t \mathrm{i}$ de grammatiske end i de leksikalske ord.

Bogstavsøgningsundersøgelser af andre sprog end dansk peger i samme retning: Grammatiske ord vies mindre opmærksomhed end leksikalske (fx Smith \& Groat 1979; Rosenberg \& al. 1985). Også andre typer undersøgelser 
af sproglig opmærksomhed peger i den retning: Ændringsblindhedsundersøgelser viser, at man er mindre opmærksom på ændringer i grammatiske ord end ændringer i leksikalske (fx Christensen et al. under revision; se Vinther, Boye \& Kristensen 2014 for yderligere diskussion). Det skal dog nævnes, at de fleste undersøgelser ikke er baseret på en teoretisk forankret distinktion mellem grammatik og leksikon. I et bogstavsøgningsforsøg fandt Foucambert \& Zuniga (2012), at præpositioner grupperer sig mellem på den ene side determinativer og konjunktioner, der antages at være grammatiske, og på den anden adverbier, adjektiver, substantiver og verber, der antages at være leksikalske. Som påpeget i Boye \& Bastiaanse (2018: 4) er det nærliggende at se dette som et udtryk for, at gruppen af præpositioner har både grammatiske og leksikalske medlemmer.

\section{Bogstavsøgningstesten}

\subsection{Prapositionskontraster}

Som omtalt i afsnit 2.3 kontrasterer vi tre grammatiske præpositionsvarianter: for og grammatiske varianter af efter og fra, med tre leksikalske varianter: for og leksikalske varianter af efter og fra. Der er i afsnit 2.3 redegjort for klassifikationen af disse varianter som hhv. grammatiske og leksikalske. Her skal det dog noteres, at de tre kontrastpar indeholder kontraster af forskellig størrelse. Størst forskel er der på for og for. De er klart forskellige både udtryks- og indholdsmæssigt: Den relevante betydningsvariant af for markerer benefaktiv, mens for er temporal (se (2a-b)). Dernæst kommer parret med grammatisk og leksikalsk efter. Det består af to udtryksmæssigt identiske varianter, der dog adskiller sig indholdsmæssigt: Grammatisk efter angiver atelicitet, mens leksikalsk efter er temporalt (se (3a-b)). Mindst forskel er der på grammatisk og leksikalsk fra. De to betydningsvarianter er udtryksmæssigt identiske, og de adskiller sig kun lidt indholdsmæssigt: Grammatisk fra angiver abstrakt kilde, mens leksikalsk fra markerer lokativisk kilde (se (4a-b)).

Præpositionsparrene blev kontrasteret i sætningspar. Parrene blev konstrueret, så de var minimalpar eller i hvert fald mindst muligt forskellige fra hinanden. Eksempler på sætningskontrasterne findes i (2) - (4) ovenfor.

\subsection{Stimuli}

Bogstavsøgningstesten består af to versioner af en tekst på 614 ord. De to tekstversioner er identiske med undtagelse af de sætninger, der kontra- 
steres. Der er i alt 10 sætningskontraster, idet kontrasten mellem for og for repræsenteres fire gange i hver tekstversion, mens hver af præpositionskontrasterne med efter og fra repræsenteres tre gange i hver tekstversion: to gange ved den leksikalske variant og en gang ved den grammatiske i den ene version, og to gange ved den grammatiske og en ved den leksikalske $i$ den anden version. De to tekstversioner indeholder således tilsammen lige mange leksikalske og grammatiske præpositionsvarianter.

Teksten blev konstrueret til formålet. For at undgå priming blev targetpræpositionerne kun anvendt i de ti kontrasterende sætninger (jf. Trofimovich \& McDonough 2009: 1). Eftersom yderpositioner på en linje kan tiltrække sig mere opmærksomhed (Smith \& Groat 1979: 318-319), blev tekstversionerne formateret, så targetordene er placeret omtrent midt på linjen. Teksten handler om en fest og giver mange detaljerede oplysninger. Disse oplysninger blev der spurgt til i en række forståelsesspørgsmål, der blev fabrikeret for at minimere risikoen for, at forsøgspersoner skannede teksten for targetbogstaver.

Testen blev udskrevet dobbeltsidet med tekstdelen på forste side og forståelsesspørgsmålene på bagsiden. En samtykkeerklæring var klipset uden på tekstdelen og fungerede dermed som forside, sådan at det ikke var muligt at kigge på teksten, før testen gik i gang.

\subsection{Forsøgsdeltagere}

I alt har 93 personer frivilligt gennemført forsøget, hvoraf 12 måtte frasorteres. Af de 81 tilbageværende deltagere var 54 kvinder, 25 mænd, og to angav sig som værende af andet køn. Deltagerne var mellem 18 og 38 år gamle, og gennemsnitsalderen lå på 22,5 år. Informanterne var alle studerende på Københavns Universitet og læste forskellige humanistiske eller samfundsvidenskabelige uddannelser. Ingen læste lingvistik.

De frasorterede omfatter medicinerede, ordblinde, personer, der ikke har angivet dansk som modersmål, personer, der havde en score på under 1 i forståelsesspørgsmålene (se afsnit 3.4), og personer, der brugte mere end ti minutter på at læse teksten.

\subsection{Fremgangsmåde}

Forsøgene foregik under tilstedeværelse af en forsøgsleder. Begge tekstversioner blev testet af samme antal informanter (inden frasortering). Forsøgsdeltagerne blev instrueret mundtligt af forsøgslederne forud for testen. De fik at vide, at formålet med undersøgelsen var at teste multitasking under læsning, og at de havde cirka 5-8 minutter til at læse teksten, men at de i 
øvrigt skulle gøre det så hurtigt som muligt. Deltagerne fik besked på at strege alle forekomster af $r$ ud, mens de læste. De blev også instrueret i at læse teksten med henblik på at forstå indholdet, så de var i stand til at svare så korrekt som muligt på de efterfølgende forståelsesspørgsmål.

Endelig blev de instrueret $i$ kun at læse teksten en gang og efter endt gennemlæsning at vende arket, notere deres tidsforbrug (et ur var synligt for alle deltagere) og derefter besvare forståelsesspørgsmålene. Efter ti minutter blev alle deltagere bedt om at gå videre til forståelsesspørgsmålene, uanset om de var færdige med at læse eller ej. En pilottest viste, at langt de fleste deltagere kunne nå at læse teksten igennem på den tid. Tidsbegrænsningen var nødvendig for at sikre, at folk ikke var alt for grundige i deres bogstavsøgning.

\subsection{Data og analyse}

For hver deltagers bogstavsøgning registreredes andelen af oversete targetpræpositioner pr. targetord og pr. tekst. Eftersom hver targetpræpositions status som grammatisk eller leksikalsk var kendt, kunne andelen af oversete grammatiske og leksikalske targetord let beregnes.

Der blev også beregnet en score for hver deltagers besvarelse af de seks forståelsespørgsmål. Der blev givet et point pr. rigtigt svar og et halvt for svar, der indikerede, at deltageren kunne huske konkrete detaljer fra teksten og dermed ikke udelukkende havde skannet teksten for targetbogstaver. Der kunne altså maksimalt opnås seks point for besvarelserne.

Derudover blev køn, alder, uddannelse, modersmål, eventuelle kommentarer til testen samt læsetid registreret.

Statistiske tests blev udført ved hjælp af R (R Core Team 2017). Bogstavsøgningsdata viste sig at være normalfordelt. For at kunne bestemme, om der er en signifikant forskel på den grammatiske og leksikalske betingelse, kunne vi derfor anvende en parret t-test. Ud over at teste, om der var en overordnet forskel på grammatiske og leksikalske præpositionsvarianter, undersøgte vi, om der var forskelle inden for hvert kontrastpar.

\section{Resultater}

Som illustreret i figur 1 overså forsøgsdeltagerne flere $r$ 'er i grammatiske præpositionsvarianter $(61 \%$; $=405$; middelværdi 0,61 ; SE 0,03$)$ end i leksikalske $(41 \%$; $=405$; middelværdi 0,41 ; SE 0,03$)$. Forskellen var signifikant $(t(80)=6,62, p<0,001, \mathrm{r}=0,60)$. 


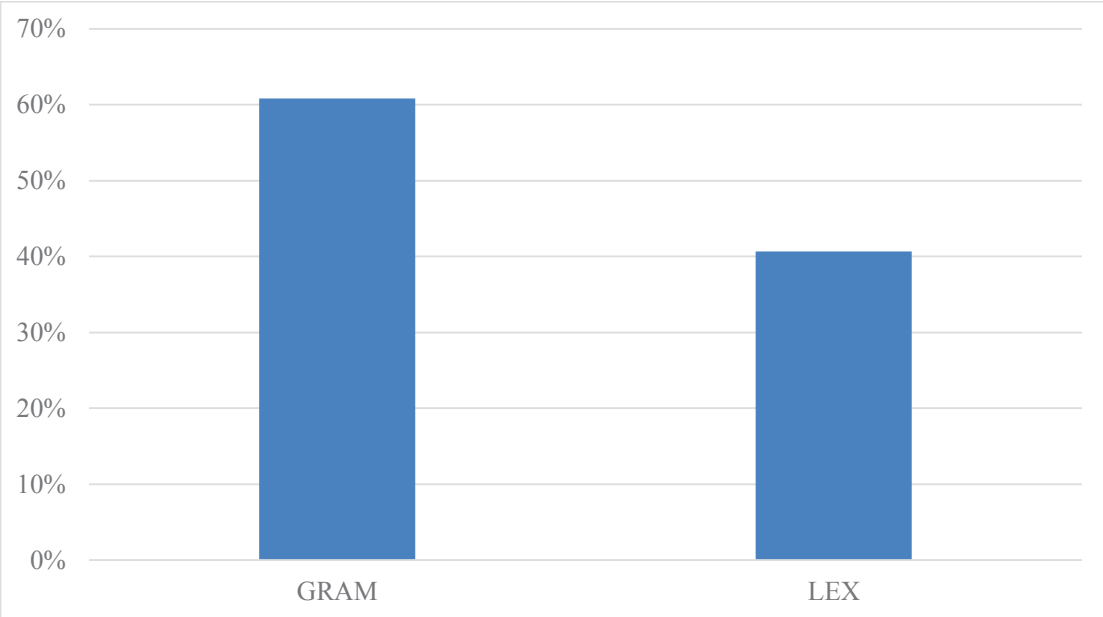

Figur 1: Gennemsnitlig fejlandel for alle prapositionsvarianter.

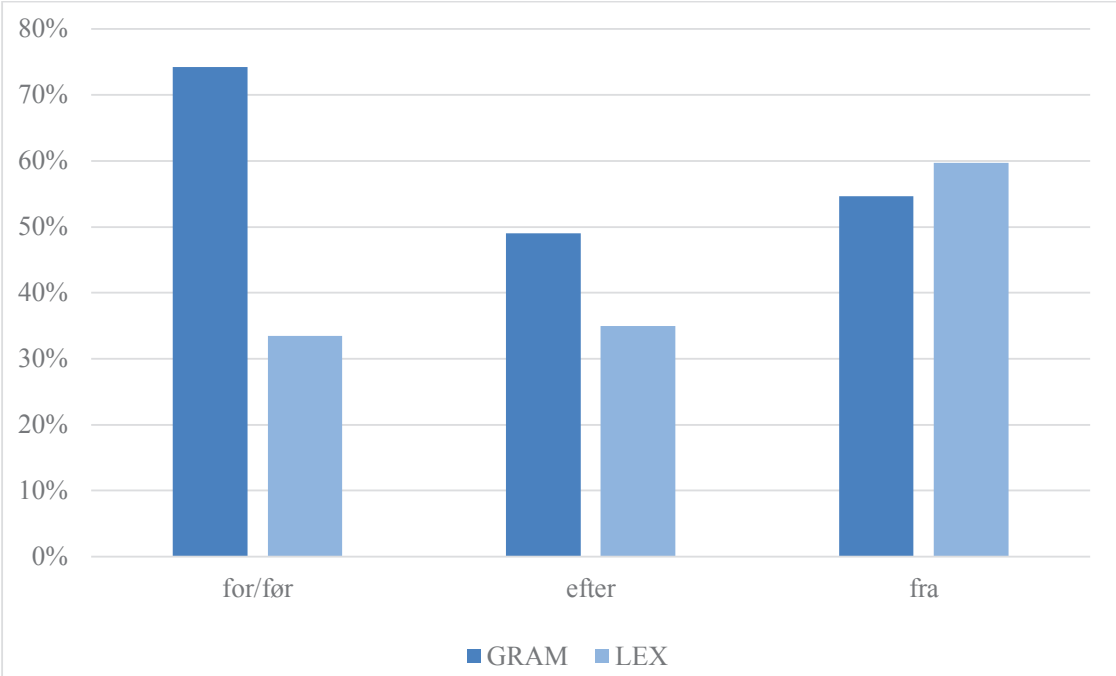

Figur 2: Gennemsnitlig fejlandel for hvert prepositionsvariantpar. 
Der er imidlertid ikke signifikant forskel inden for hvert enkelt præpositionsvariantpar. Som illustreret i figur 2 overså forsøgsdeltagerne $60 \%(n=121)$ af forekomsterne af grammatisk fra, men $55 \%(\mathrm{n}=122)$ af forekomsterne af leksikalsk fra. Denne forskel er ikke signifikant $(t(80)=-0,9666, p=0,3367)$. Det er altså de to øvrige par, der bærer den overordnede signifikante forskel. Forsøgsdeltagerne overså $75 \%(n=162)$ af forekomsterne af grammatisk for $\bmod 34 \%(\mathrm{n}=162)$ af forekomsterne af leksikalsk for. Denne forskel er signifikant $(t(80)=9,6933, p<0,001)$. De overså $49 \%(\mathrm{n}=122)$ af forekomsterne af grammatisk efter mod $35 \%(\mathrm{n}=121)$ af forekomsterne af leksikalsk efter. Denne forskel er ligeledes signifikant $(t(80)=2,3035, p<0,05)$.

Vi fandt (ikke overraskende) en overordnet sammenhæng mellem tidsforbrug og bogstavsøgning: Jo længere tid, man har brugt, desto færre targetord har man overset. Vi fandt også en overordnet tendens til, at deltagerne overså desto flere targetord, jo tættere på slutningen af teksten ordene befandt sig. Derimod fandt vi ikke nogen tydelig sammenhæng mellem bogstavsøgning og besvarelserne af forståelsesspørgsmål.

\section{Diskussion}

I overensstemmelse med Boye \& Harders teori om forskellen på grammatik og leksikon var undersøgelsens hypotese, at man er mindre opmærksom på og derfor overser flere targetbogstaver i grammatiske præpositionsvarianter end i leksikalske præpositionsvarianter i en bogstavsøgningstest. Hypotesen blev overordnet set bekræftet på signifikant niveau, men kun to af de tre kontrasterede præpositionsvariantpar følger den overordnede tendens, og de gør det i forskellig grad: Der er størst og signifikant forskel på grammatisk for og leksikalsk for, mindre, men signifikant forskel på grammatisk og leksikalsk efter og ingen signifikant forskel på grammatisk og leksikalsk fra.

Nedenfor argumenterer vi først for, at denne variation hverken er betinget af forsøgsdesignforhold (afsnit 5.1) eller frekvensforskelle (5.2). Derefter argumenterer vi for, at variationen kan forstås som betinget af et grammatikaliseringskontinuum, i hvilket et grammatisk element gradvis uddestilleres af en leksikalsk kilde og til slut får en selvstændig kognitiv repræsentation (5.3).

Inden da skal vi for fuldstændighedens skyld bemærke, at der ikke er nogen oplagt fonologisk forklaring på variationen. Fra-varianterne, der skiller sig ud i bogstavsøgningsresultaterne, skiller sig oplagt også ud ved deres r-lyd, men r-lyden er netop fælles for begge varianter. 


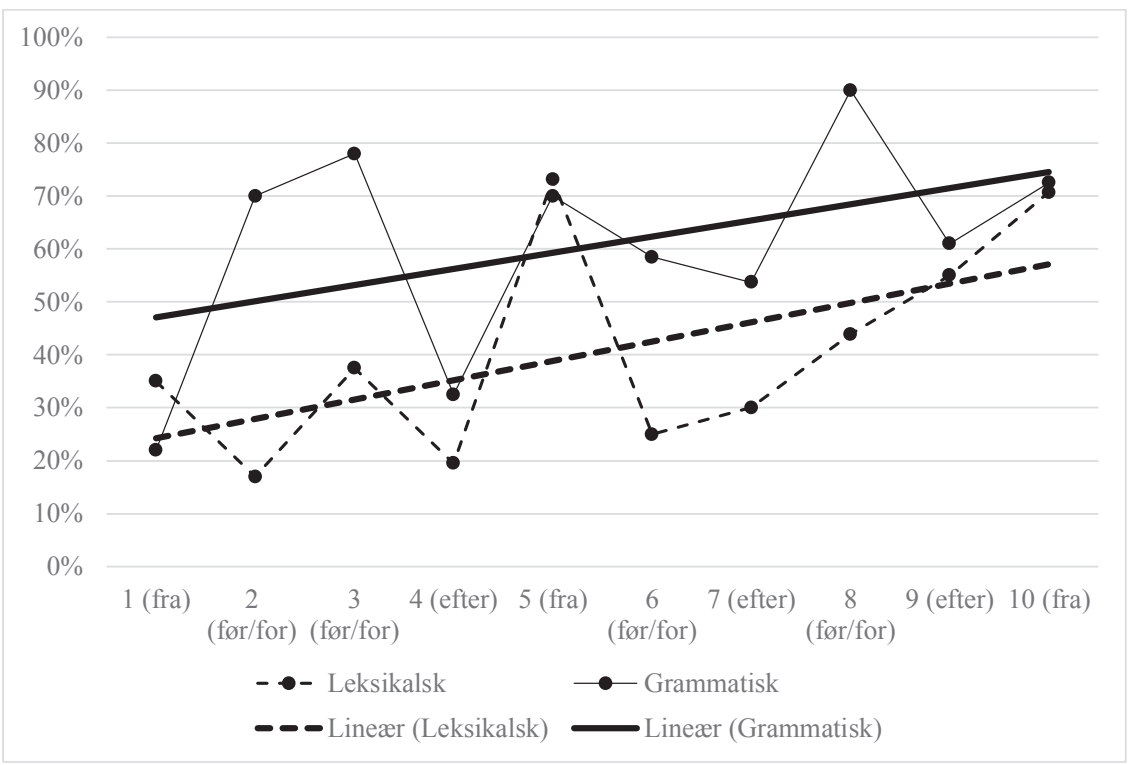

Figur 3: Fejlandel fordelt på targetordene og deres pladser.

\subsection{Designforhold kan ikke forklare variationen}

Som nævnt i afsnit 5 fandt vi en overordnet tendens til, at deltagerne overså desto flere targetord, jo tættere på slutningen af teksten ordene befandt sig, en såkaldt fatigue-effekt. Det er nærliggende at overveje, om denne tendens kan forklare den variation, vi har fundet i bogstavsøgningsresultaterne for de tre præpositionskontraster, vi har undersøgt. Dette ville være tilfældet, hvis alle forekomster af $f r a$-varianterne befandt sig til slut i teksten, og hvis der her blev fundet for få bogstaver til at bære en signifikant forskel på de to betingelser. Men som det fremgår af figur 3, der viser resultaterne af vores undersøgelse af sammenhængen mellem tekstplacering og bogstavsøgning, holder denne forklaring ikke. For det første blev fra-varianterne ikke kun kontrasteret i slutningen af teksten (kontrastplads 10), men også i begyndelsen (plads 1) og i midten (plads 5). For det andet er der stadig tendens til, at en betragtelig andel targetbogstaver findes selv i slutningen af teksten (tendenslinjerne (de fede og lige) i figur 3 er ikke i nærheden af 100\%).

\subsection{Frekvensforskelle kan ikke forklare variationen}

Det er veldokumenteret, at frekvens har indflydelse på opmærksomhed: Jo hyppigere et element er, desto mere tilbøjelige er vi til at overse det (Healy 1976; Koriat \& Greenberg 1991). Da grammatiske ord og betydningsvarian- 
ter ofte er højfrekvente, kunne det tænkes, dels at den overordnede forskel, vi fandt på grammatiske og leksikalske præpositioner, grundlæggende er frekvensbetinget, dels at variationen i de tre kontrastpar er frekvensbetinget: Det kunne fx formodes, at fra-varianterne skiller sig ud ved at være nogenlunde lige frekvente.

Alle de præpositioner, der er udvalgt til undersøgelsen, er blandt de 100 mest frekvente danske ord (at dømme efter en frekvensliste over de 3000 mest brugte danske ord fra Korpus 2000: http:/ /www.copenhagencast.com/ learningcenter/3000mostfrequentDanishwords.pdf). Men det er naturligvis ikke ensbetydende med, at de betydningsvarianter, vi undersøgte, alle er højfrekvente. For at undersøge, om præpositionsvarianternes frekvens har påvirket resultaterne, har vi foretaget en frekvensanalyse ved hjælp af en stikprøve af data fra KorpusDK.

Resultatet af frekvensanalysen frembyder et mønster, der ikke harmonerer med bogstavsøgningsmønsteret. Grammatisk for er ganske vist langt mere frekvent end leksikalsk for (98\% mod 2\%), hvilket kunne forklare bogstavsøgningsforskellen for de to varianters vedkommende. Men grammatisk fra er også langt mere frekvent end leksikalsk fra $(78 \%$ mod $20 \%$, med $2 \%$ irrelevante forekomster), og fra-varianterne udviste netop ingen signifikant bogstavsøgningsforskel. Dertil kommer, at grammatisk efter faktisk er mindre frekvent end leksikalsk efter $(15 \% \bmod 61 \%$, med $24 \%$ irrelevante forekomster), hvilket udelukker en frekvensforklaring på bogstavsøgningsforskellen for disse to varianters vedkommende. Der er altså så lidt sammenhæng, som overhovedet kan tænkes, mellem frekvensmønstrene og bogstavsøgningsmønstrene, og en frekvensforklaring på de sidstnævnte må forkastes.

\subsection{Variationen afspejler et grammatikaliseringskontinuum}

Nøglen til en forståelse af variationen i bogstavsøgningsresultaterne ligger i de observationer om kontrastparrene, vi gjorde i afsnit 2.1. Her nævnte vi, at de tre kontrastpar indeholder kontraster af forskellig størrelse. De tre par danner med andre ord et kontinuum, der har at gøre med, hvor beslægtede de kontrasterede betydningsvarianter er. Dette kontinuum spejles nøje i det kontinuum, vi fandt i vores resultater: For og for adskiller sig klart både udtryks- og indholdsmæssigt, og dette par udviser den største bogstavsøgningsforskel. Grammatisk og leksikalsk efter adskiller sig kun indholdsmæssigt, men dog relativt klart (i forhold til grammatisk og leksikalsk fra), og dette par udviser en mindre, men stadig signifikant bogstavsøgningsforskel. Grammatisk og leksikalsk fra adskiller sig kun ind- 
holdsmæssigt og kun relativt svagt (i forhold til grammatisk og leksikalsk efter), og dette par udviser ingen forskel.

I det følgende vil vi argumentere for, at variationen i bogstavsøgningsresultaterne for de tre kontrastpar kan forstås som betinget af - og giver ny indsigt $\mathrm{i}$ - et grammatikaliseringskontinuum, i hvilket et grammatisk element gradvis uddestilleres af en leksikalsk kilde og til slut får en selvstændig kognitiv repræsentation.

Argumentationen kræver en præcis forståelse af bogstavsøgning og teorien i Boye \& Harder (2012). Det er for det første vigtigt at forstå, at bogstavsøgningsforskelle forudsætter, at de sammenlignede størrelser (fx ord) har forskellige kognitive repræsentationer: Hvis den samme kognitive repræsentation aktiveres af begge sammenlignede størrelser, og hvis denne repræsentation er associeret med en vis diskursprominens, må det forventes, at der ingen bogstavsøgningsforskel er på de to sammenlignede størrelser.

For det andet er det vigtigt at forstå, at teorien om grammatisk status og grammatikalisering i Boye \& Harder (2012) ikke er en teori om kognitive repræsentationer. Den kan bruges til at afgøre, om en given sproglig størrelse er grammatisk eller leksikalsk, og den forudsætter således, at man kan skelne sproglige størrelser fra hinanden. Men den er ikke en teori om, hvordan og hvornår sådanne størrelser kan skelnes, eller om hvordan og hvornår der kan skelnes tilsvarende kognitive repræsentationer.

Vi har i vores undersøgelse på grundlag af udtryks- og især indholdsforskelle kontrasteret tre gange to betydningsvarianter af præpositioner, og vi har på grundlag af teorien i Boye \& Harder (2012) identificeret de tre kontraster som kontraster mellem grammatiske og leksikalske varianter. Men i lyset af ovenstående er det klart, at der ingen garanti er for, at disse varianter har distinkte kognitive repræsentationer.

Bogstavsøgningsresultaterne skal efter vores mening netop forstås som betinget af, i hvilken grad de kontrasterede præpositionsvariantpar har distinkte repræsentationer. Man kan forestille sig et kontinuum som illustreret i figur 4.

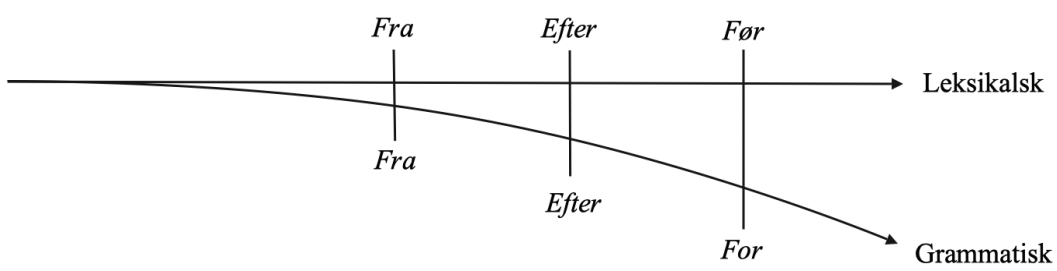

Figur 4: Grammatikaliserings- eller uddestilleringskontinuum. 
I den ene ende af kontinuummet finder vi kontrasten mellem grammatisk for og leksikalsk for, der klart er distinkte størrelser, og derfor udviser den klareste bogstavsøgningsforskel. I den anden ende finder vi kontrasten mellem grammatisk og leksikalsk fra, der kun udviser en indholdsforskel og kun en relativt lille en, og som derfor kan antages ikke at have distinkte repræsentationer. Denne antagelse forklarer, hvorfor de ikke udviser nogen signifikant bogstavsøgningsforskel. Imellem disse to yderpositioner i kontinuummet finder vi kontrasten mellem grammatisk og leksikalsk efter. Forskellen på disse to varianter er mindre end forskellen på for og for: Der er som nævnt kun tale om en forskel på indholdssiden, men forskellen er relativt stor. Det er derfor nærliggende at antage, at de to varianter ikke i samme grad som for og for er associeret med distinkte repræsentationer. Denne antagelse forklarer, hvorfor efter-kontrasten giver en bogstavsøgningsforskel, der er mindre end den for for-før-kontrasten, men større end den for fra-fra-kontrasten.

Figur 4 er altså på en og samme gang en illustration af tre relaterede kontinua: 1) et kognitivt repræsentationskontinuum, 2) et dermed associeret sprogligt grammatikaliserings- eller uddestilleringskontinuum og 3) et deraf betinget bogstavsøgningskontinuum.

Kontinuaene i figur 4 kan ikke i nærværende sammenhæng tolkes diakront, for for er ikke udviklet af for. Men det er oplagt, at en generaliseret version af kontinuaene kan tolkes diakront: Med tiden udvikler et tegn, der har én samlet kognitiv repræsentation, indholdsvarianter med forskellig repræsentation, hvorefter indholdsvarianterne udspalter sig i forskellige tegn.

\section{Konklusion}

Teorien om grammatisk status i Boye \& Harder (2012) indebærer dels en skelnen mellem grammatiske og leksikalske præpositionsvarianter i dansk, dels en hypotese om, at førstnævnte tiltrækker sig mindre opmærksomhed end sidstnævnte. I denne artikel har vi på baggrund af det modifikationskriterium, der blev udviklet i Messerschmidt et al. (2018) identificeret tre grammatiske og tre leksikalske præpositionsvarianter. Disse varianter har vi kontrasteret to og to i en bogstavsøgningstest. De overordnede resultater af testen bekræfter opmærksomhedshypotesen, og dermed underbygger de - i lighed med den afasiologiske undersøgelse i Messerschmidt et al. (2018) - den teoretisk funderede sondring mellem grammatiske og leksikalske præpositionsvarianter. 
Bekræftelsen af opmærksomhedshypotesen bæres af to af de tre præpositionsvariantpar. For det tredje par fandt vi ingen signifikant forskel i bogstavsøgning. Dette præpositionspar har de to varianter, der ligner hinanden mest, og vi har argumenteret for, at bogstavsøgningsresultaterne forstås som betinget af - og giver ny indsigt $\mathrm{i}$ - et grammatikaliseringskontinuum, $\mathrm{i}$ hvilket et grammatisk element gradvis uddestilleres af en leksikalsk kilde og til slut får en selvstændig kognitiv repræsentation.

\section{Om forfatterne}

Kasper Boye, ph.d., lektor i lingvistik, Institut for Nordiske Studier og Sprogvidenskab, Københavns Universitet.

Maria Messerschmidt, cand.mag. i lingvistik og ph.d.-stipendiat, Institut for Nordiske Studier og Sprogvidenskab, Københavns Universitet.

Josefine Straube Hansen, stud.mag. i lingvistik, Institut for Nordiske Studier og Sprogvidenskab, Københavns Universitet.

Victoria Schaffalitzky de Muckadell, stud.mag. i lingvistik, Institut for Nordiske Studier og Sprogvidenskab, Københavns Universitet.

\section{Litteratur}

Bordet, L. \& Jamet, D. (2010): Are English prepositions lexical or grammatical morphemes? Cercles, Occasional Papers, 1-26.

Boye, K., \& Bastiaanse, R. (2018): Grammatical versus lexical words in theory and aphasia: Integrating linguistics and neurolinguistics. Glossa: a journal of general linguistics, 3(1), 29. DOI: 10.5334/gigl.436

Boye, K. \& Harder, P. (2012): A usage-based theory of grammatical status and grammaticalization. Language, 88(1), 1-44.

Chomsky, N. (1981): Lectures on Government and Binding. Dordrecht: Foris.

Christensen, M.H., Kristensen, L.B., Vinther, N.M. \& Boye, K. (Under revision). Grammar is background in sentence processing.

Foucambert, D. \& Zuniga, M. (2012): Effects of Grammatical Categories on Letter Detection in Continuous Text. Fournal of Psycholinguistic Research, 41: 33. DOI: 10.1007/s10936-011-9175-1.

Friederici, A.D. (1982): Syntactic and semantic processes in aphasic deficits: The availability of prepositions. Brain and Language, 15(2), 249-258.

Harley, H. (2006): English words: A linguistic introduction. New York: John Wiley \& Sons. 
Healy, A.F. (1976): Detection errors on the word the: Evidence for reading units larger than letters. Fournal of Experimental Psychology: Human Perception and Performance, 2, 235-242.

Ishkhanyan, B., Sahraoui, H., Harder, P., Mogensen, J. \& Boye, K. (2017): Grammatical and lexical pronoun dissociation in French speakers with agrammatic aphasia: A usage-based account and REF-based hypothesis. Fournal of Neurolinguistics, 44, 1-16.

Jackendoff, R. (1973): The Base Rules for Prepositional Phrases. I: Anderson, S. \& Kiparsky, P. (red.). A Festschrift for Morris Halle. New York: Holt, Rienhart and Winston, 345-356.

Kalledsøe, L.J., Vinther, N.M. \& Boye, K. (2016): Hvornår begynder sondringen mellem grammatik og leksikon at påvirke skriftsprogsprocesseringen? Logos: Audiologopadisk tidsskrift, 78, 24-26.

Kean, M.-L. (1979): Agrammatism: A phonological deficit? Cognition, 7, 69-83.

Koriat, A. \& Greenberg, S.N. (1991): Syntactic control of letter detection: Evidence from English and Hebrew nonwords. Fournal of Experimental Psychology: Learning, Memory, and Cognition, 17(6), 1035-1050.

Leikin, M. (2002): Locative prepositions in language acquisition and aphasia. I: Feigenbaum, S. \& Kurzon, D. (red.). Prepositions in their syntactic, semantic, and pragmatic context. Amsterdam: John Benjamins, 283-299.

Littlefield, H. (2005): Lexical and Functional Prepositions in Acquisition: Evidence for a Hybrid Category. Boston University Conference on Language Development 29, Online Proceedings Supplement.

Mardale, A. (2011): Prepositions as a semilexical category. Bucharest Working Papers in Linguistics, 13, 35-50.

Messerschmidt, M., Boye, K., Overmark, M.M., Kristensen, S.T. \& Harder, P. (2018): Sondringen mellem grammatiske og leksikalske præpositioner. Ny forskning i grammatik 25. 89-106.

$\mathrm{R}$ Core Team (2017): $R$ : A language and environment for statistical computing. $\mathrm{R}$ Foundation for Statistical Computing, Wien. URL https://www.Rproject.org/

Rosenberg, B., Zurif, E., Brownell, H., Garrett, M. \& Bradley, D. (1985): Grammatical Class Effects in Relation to Normal and Aphasic Sentence Processing. Brain and language, 26, 287-303.

Smith, P.T. \& Groat, A. (1979): Spelling patterns, letter cancellation and the processing of text. I: Koolers, P.A., Wrolstad, M.E. \& Bouma, H. (red.). Processing of Visible Language. Proceedings of the first Conference on Processing of Visible Language. New York: Plenum: 309-324. 
Trofimovich, P. \& McDonough, K. (2009): Using priming methods in second language research. New York: Routledge.

Vinther, N.M., Boye, K. \& Kristensen, L.B. (2014):. Grammatikken i baggrunden - opmærksomhed under læsning. Ny $S$ - Nydanske Sprogstudier, 47, 99-139. 